\title{
Thin Crust as Evidence for an Inherited Mantle Depletion Supporting the Marion Rise
}

\author{
Huaiyang Zhou* and Henry JB Dick** \\ * State Key Laboratory of Marine Geology, Tongji University, Shanghai, China \\ **Woods Hole Oceanographic Institution, Woods Hole, Massachusetts 02543, USA
}

The global ridge system is dominated by oceanic rises reflecting large variations in axial depth associated with mantle hotspots. The little studied Marion Rise is as large as the Icelandic, considering length and depth, but has an axial rift rather than a high nearly its entire length. Uniquely, along the SW Indian Ridge systematic sampling allows direct examination of crustal architecture over its full length. Unlike Iceland, peridotites are extensively exposed high over the rise. This shows for the $1^{\text {st }}$ time that the crust is generally thin, and often missing over a rifted rise. Thus the rise must be largely an isostatic response to ancient melting events that created low-density depleted mantle beneath the ridge rather than thickened crust and/or a large thermal anomaly. The likely origin for the depleted mantle is that emplaced into the African asthenosphere during the Karoo and Madagascar flood basalt events.

Following Morgan ${ }^{1}$, common wisdom equates oceanic rises to a hot fertile mantle plume producing a flow of plume-derived mantle to the ridge and down the sub-axial asthenospheric channel, resulting in elevated mantle temperature, ridge topography, and thickened igneous crust (the mantle wedge hypothesis, e.g.: ${ }^{2}$ ). Studies of the Reykjanes Ridge support this, with seismic crust thickening from $\sim 6 \mathrm{~km}$ near the Gibbs FZ for 1600 $\mathrm{km}$ to $\sim 18 \mathrm{~km}$ at the Reykjanes Peninsula e.g.: ${ }^{3}$. The Icelandic Rise, also has a long axial high consistent with such robust magmatism ${ }^{4}$ (Table 1 ). The current consensus is the igneous crust thickens from east to west up the Marion Rise, and indeed up all rises (e.g.:

${ }^{56}$ ). Basalt sodium contents, like other rises, decrease systematically towards Marion, and are interpreted to represent higher degrees of mantle melting and thicker crust ${ }^{7}$. Dick et al. ${ }^{8}$, however, point out that such correlations can be due to variable mantle temperature, or an increasingly depleted mantle source composition, and do not require thicker crust. The Marion Rise, in particular, has numerous large-offset transforms that would block sub-axial asthenospheric flow (e.g.: ${ }^{9}$ ), and its deep rift valley indicates anemic rather than robust magmatism ${ }^{4}$. Niu and O'Hara ${ }^{10}$, though assuming thick crust over rises, suggest the global correlation of basalt chemistry and ridge depth is best explained by mantle composition variations, with many rises supported by depleted chemically buoyant mantle as first proposed by O'hara ${ }^{11}$ for the Iceland Rise and Presnall and Helsley ${ }^{12}$ for the Azores. 
Table I. Characteristics of Rifted and Axial Rises

\begin{tabular}{|c|c|c|c|c|c|c|c|c|c|c|}
\hline Rise & $\begin{array}{c}\text { Dominant } \\
\text { Morph- } \\
\text { ology }\end{array}$ & $\begin{array}{c}\text { Spreading } \\
\text { Rate } \\
(\mathrm{mm} / \mathrm{yr})\end{array}$ & $\begin{array}{c}\text { Hotspot } \\
\text { Magma } \\
\text { Flux } \\
\left(\mathrm{m}^{3} / \mathrm{s}\right)^{\mathrm{a}}\end{array}$ & $\begin{array}{c}\text { Crustal } \\
\text { Vol. }^{\text {b }} \\
\left(10^{7} \mathrm{~km}^{3}\right)\end{array}$ & $\begin{array}{c}\text { Max } \\
\text { \&Min. } \\
\text { Elevation } \\
(\mathrm{m})^{c}\end{array}$ & $\begin{array}{c}\text { Max \&Min. } \\
\text { Elevation, } \\
200 \mathrm{~km} \text { ave. } \\
(\mathrm{m})^{\mathrm{d}}\end{array}$ & \begin{tabular}{|c|} 
Depth \\
Anoma \\
ly \\
$(\mathrm{m})^{\mathrm{e}}$
\end{tabular} & $\begin{array}{l}\text { Rise } \\
\text { Length } \\
(\mathrm{km})^{c}\end{array}$ & $\begin{array}{l}\text { Cross- } \\
\text { section } \\
\text { Area km² }\end{array}$ & $\begin{array}{c}\text { Geographic } \\
\text { Location }\end{array}$ \\
\hline Iceland & Axial high & 19.5 & 7.0 & 4.53 & $\begin{array}{c}750 \\
-3115 \mathrm{~m}\end{array}$ & $\begin{array}{c}642 \\
-2425\end{array}$ & 3067 & 2390 & $3,665,156$ & $\begin{array}{c}\text { Jan Mayen to } \\
\text { Gibbs FZ @ 53오 }\end{array}$ \\
\hline Galapagos & Axial high & 63.0 & 5.5 & & $\begin{array}{l}-1361 \\
-3732\end{array}$ & $\begin{array}{l}-1762 \\
-3170\end{array}$ & 1408 & 1380 & 970,988 & $\begin{array}{c}\text { ocos Nazca Ridge } \\
\text { @ } 2^{\circ} \mathrm{N}\end{array}$ \\
\hline Azores & Axial rift & 20.5 & & 1.15 & $\begin{array}{l}-345 \\
-4127\end{array}$ & $\begin{array}{l}-1659 \\
-3441\end{array}$ & 1782 & 2877 & $2,563,557$ & $\begin{array}{c}\text { MAR } 47.5^{\circ} \text { to } \\
25.8^{\circ} \mathrm{N}\end{array}$ \\
\hline Marion & Axial rift & 14.6 & 0.4 & 0.95 & $\begin{array}{l}-858 \\
-5150\end{array}$ & $\begin{array}{l}-2547 \\
-4681\end{array}$ & 2134 & 3408 & 3,636,236 & \begin{tabular}{|c|} 
SWIR \\
$32.32^{\circ}$ to $63.34^{\circ} \mathrm{E}$
\end{tabular} \\
\hline
\end{tabular}

Notes: a) Marion - Zhang et al. ${ }^{14}$; b) Iceland\& Azores - Wang et al. ${ }^{5}$; Galapagos - Canales et al. ${ }^{6}$; Marion - Zhang et al. ${ }^{14}$. c) Maximum and minimum elevations are measured from shallowest point on axis, or midpoint of Iceland plateau to the rift valley axis point where average depth stabilizes or blocking transform. d) The 200-km average represents average elevation about the highest or lowest point. e) Iceland average plateau height; crest of Azores Rise, SWIR @ 36²15Ed) MAR @ Charlie Gibbs FZ; axial

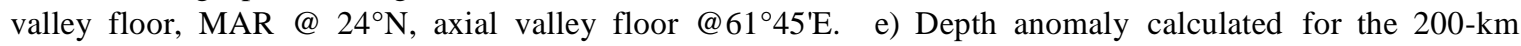
averages to eliminate local topographic effects. Note that measured by the total rise length and rise height, the Iceland and Marion Rises are equally large within error ( 1/2 x Height $\mathrm{x}$ Length).

The only available seismic data predicts $2-6 \mathrm{~km}$ of crust in the SW Indian Ridge (SWIR) rift mountains at $57^{\circ} \mathrm{E}$ and $61^{\circ} \mathrm{E}^{13}$. Modeling using sea surface gravity gives 2-4 $\mathrm{km}$ in the eastern SWIR, but around 6 to $12 \mathrm{~km}$ north of Marion Island ${ }^{14}$. Six to $12 \mathrm{~km}$ of igneous crust where mantle peridotites are abundantly exposed, however, seems unlikely. Muller et al. ${ }^{15}$ found Moho at $5 \pm 1 \mathrm{~km}$ beneath Atlantis Bank at $57^{\circ} \mathrm{E}$, but concluded that it could be a serpentinization front. Similarly, the seismic determination of crustal thickness at $61^{\circ} \mathrm{E}$ is at odds with mapping east of the Melville FZ that shows the ridge consists of local magmatic centers linked by nearly amagmatic oblique segments producing "smooth" seafloor ${ }^{16}$. Hence, the equivalency of seismic and igneous 'crust' is not established for slow and ultraslow ridges (e.g.: ${ }^{17}$ ).

All estimates of ocean crust thickness are by inference from geochemistry, seismic data, and gravity. Nowhere have they been tested by direct geologic constraints, which would require deep-ocean drilling. Mapping and sampling in lower crust and mantle exposed in oceanic core complexes, however, can constrain crustal thickness (e.g.:.$^{18,19}$ ). Using this approach, the $1^{\text {st }}$ author surveyed a ridge segment at $53^{\circ} \mathrm{E}$ where low basalt $\mathrm{Na}_{8}{ }^{20}$, refractory peridotite, gravity ${ }^{14}$, and the mantle wedge hypothesis suggest $4-8 \mathrm{~km}$ of crust. Instead of thick crust, however, this found nearly amagmatic spreading, supporting our interpretation of sampling elsewhere on the ridge.

\section{Tectonic Setting}

The SWIR is a highly oblique ultraslow spreading ridge with near constant full rate of $\sim 14 \mathrm{~mm} / \mathrm{yr}^{21}$, extending 7,700 km between the Bouvet and Rodriguez Triple Junctions (Fig. 1). East of the Bouvet $\mathrm{TJ}$ at $25^{\circ} \mathrm{E}$ it is abruptly offset $\sim 1,800 \mathrm{~km}$ to the northwest by 


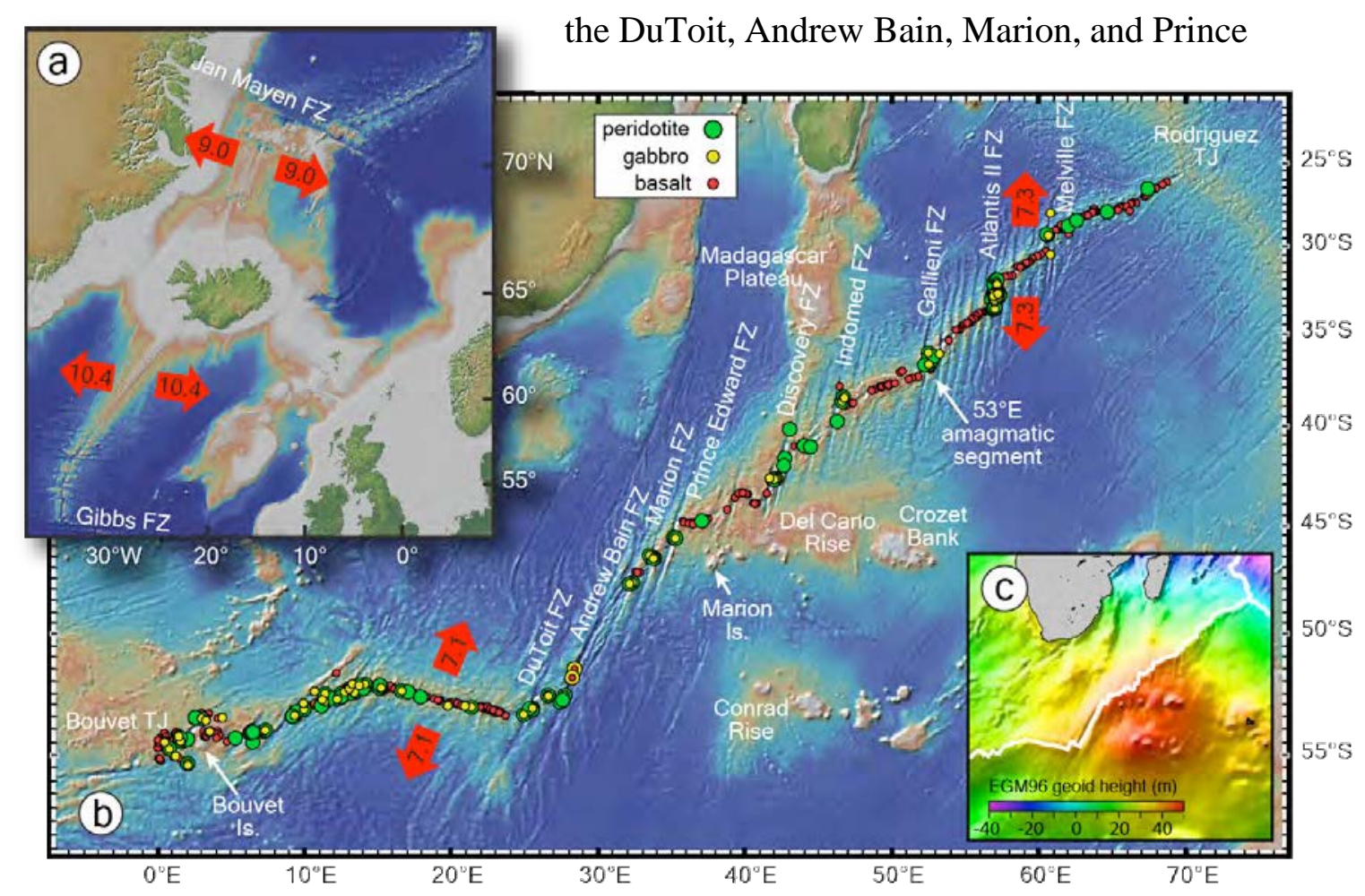

Figure 1 Physiographic and Geoid maps of the SW Indian Ridge with sample locations, and a map of the Icelandic Rise for comparison. (A) Relief map of the Icelandic Swell, (B) Map of the Marion Swell with location of satellite navigated peridotite, gabbro, and basalt dredges on the SWIR, and (C) Geoid map plotted on a $0.25 \times 0.25 \mathrm{~b}$ degree grid showing the position of the SWIR courtesy of Mark Behn. Maps plotted at the same scale for comparison (www.geomapapp.org). Spreading rates calculated using Nuvel 1 velocities. Symbol sizes are not proportional to recovery. Data and sources are given in Supplemental Table I.

Edward FZ's ${ }^{22}$. There it crosses the flank of the southern ocean geoid high, following a subdued positive arch over the Marion Swell from the Andrew Bain to the Gallieni FZ. The Marion Rise extends $\sim 3400 \mathrm{~km}$, starting at 4800-m depth at $27^{\circ} \mathrm{E}$ before rising abruptly to $-858-\mathrm{m}$ at $36^{\circ} \mathrm{E}$, and then down to $\sim 5150-\mathrm{m}$ depth at $63^{\circ} \mathrm{E}$. A $1.5-\mathrm{km}$ high $70-\mathrm{km}$-long axial volcano at $36^{\circ} \mathrm{E}$ forms a short axial ridge marking the maximum volcanic activity on the rise. This is attributed to flow of plume-derived mantle to the ridge from beneath the Marion Hotspot $256 \mathrm{~km}$ to the south ${ }^{23}$. Gravity, however, indicates that any influence of the Marion Hotspot is limited to west of the Discovery II $\mathrm{FZ}^{9,24}$. Except for the $36^{\circ} \mathrm{E}$ segment, the entire SWIR has a deep axial rift. The SWIR east of the Indomed FZ formed by propagation of the Rodriguez TJ over the last $64 \mathrm{Ma}$ ${ }^{21}$. It has regularly spaced non-transform discontinuities, short oblique amagmatic segments, and the Atlantis II, Novara, and Melville transforms.

\section{Geology}

Shown in Figure 1 is a compilation of satellite-navigated dredges (supplemental Table I), with which we interpret crustal architecture along the SWIR (see Methods Section). Peridotite and gabbro are widely distributed over the entire ridge, though most 
Figure 2 Lithologic proportions by weight for SW Indian Ridge dredges compiled from supplemental Table I with proportions for Atlantis Massif, MAR. A) SWIR excluding the Atlantis II $\mathrm{FZ}$ at $57^{\circ} \mathrm{E}$. B) Atlantis II $\mathrm{FZ}$ including Atlantis Bank. C) Atlantis Bank excluding the rest of the Atlantis II FZ. D) Atlantis Massif, MAR: lithologic proportions by number of dive samples collected on the flanking transform wall, compiled from Karson et al. ${ }^{47}$. The transform gabbros are interpreted as a precursor net-vein complex intruded into massive granular peridotite from the $1400-\mathrm{m}$ gabbro sequence drilled $4.5 \mathrm{~km}$ to the North at IODP Hole U1309D.

dredging focused on rift valley neovolcanic zones. This severely biased recoveries to basalt, as even a thin lava veneer prevents sampling plutonic rock. Dredges on rift valley walls, non-
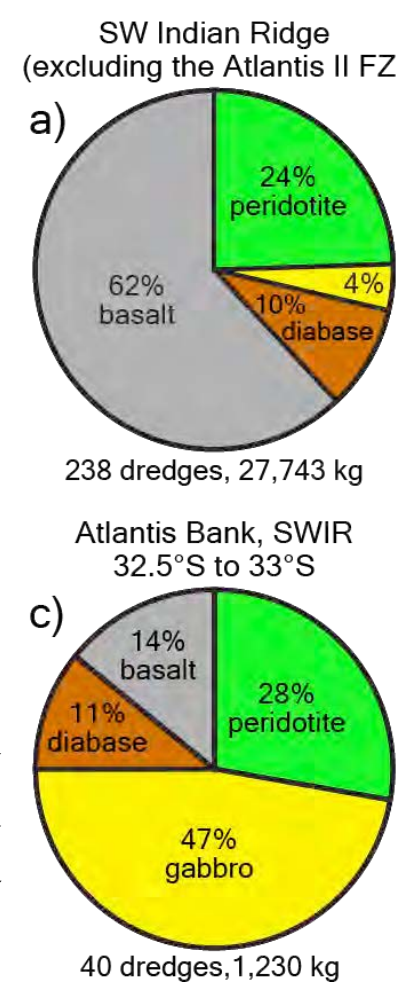

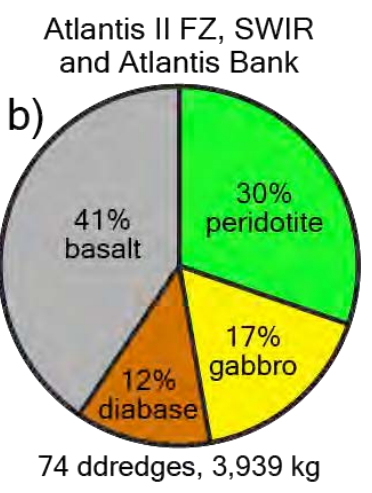

Atlantis Massif, MAR transform wall

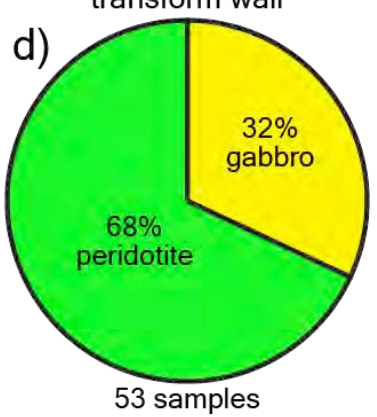
transform discontinuities, and transforms are comparatively few, except along the western SWIR and the Atlantis II FZ. From $9^{\circ}$ to $35^{\circ} \mathrm{E}$ and $41^{\circ}$ to $47^{\circ} \mathrm{E}{ }^{25}$ peridotite is abundant, demonstrating thin, or missing basaltic crust and enormous mantle exposures 25-27. Despite its frequent occurrence, however, gabbro is volumetrically scarce, and, excluding the Atlantis II FZ, accounts for $<15 \%$ of the plutonic rocks dredged along the SWIR (Fig. 2). Thus while gabbro and peridotite occur in 25 dredges at $9^{\circ}$ to $16^{\circ} \mathrm{E}$, there is $1570 \mathrm{~kg}$ of peridotite but only $49 \mathrm{~kg}$ of gabbro. With only scattered basalt flows dredged in the rift valley, this is essentially a $400-\mathrm{km}$ long 'amagmatic' segment ${ }^{28}$. Similarly while there are 21-peridotite bearing and 17-gabbro bearing Protea dredges from $31^{\circ}$ to $39^{\circ} \mathrm{E}$, they recovered $3451 \mathrm{~kg}$ of peridotite, and only $799 \mathrm{~kg}$ of gabbro.

Most SWIR peridotites are partially serpentinized (20-70\%) statically altered granular rocks with fine serpentine vein networks (Supplemental Fig.'s 1 and 2). They have protogranular texture with smooth curved grain boundaries interlocking with olivine, or overprinting porphyroclastic texture due to high-temperature crystal-plastic deformation. Associated mylonites, which constitute $\sim 5 \%$ of abyssal peridotites ${ }^{29}$, reflect extreme deformation produced by strain localization, with olivine-spinel geothermometry indicating closure temperatures of $\sim 600^{\circ}-750^{\circ} \mathrm{C}^{30}$. Talc-serpentine and talc-tremolite schist, hydrothermally altered and sheared peridotite, represent $<10 \%$ of the peridotites. These assemblages reflect progressive strain localization from high- temperature crystalplastic deformation $\left(>1000^{\circ} \mathrm{C}\right)$, followed by mylonite formation, to low-temperature brittle faulting accompanying unroofing and final emplacement to the seafloor ${ }^{19,31}$. 
Figure 3 Bathymetric map of the $53^{\circ} \mathrm{E}$ Ridge Amagmatic Segment with sample locations and contents. The Simrad EM120 multibeam map covers $\sim 11,000 \mathrm{~km}^{2}$ imbedded in sea surface gravity map from GeoMapAp. Filled circles indicate dredge and TV grab locations. Multiple lithologies indicated by nested symbols, with smaller insets representing the volumetrically lesser rock type. D and TVG prefixes represent the DY21 samples; IND - Scripps Institution of Oceanography Indomed Expedition Leg 8; MD107 - RV Marion Dufresne Cruise 107 samples. Dashed lines outline areas of probable massive exposure of peridotite ( 3200-km², western area) and gabbro ( 380 $\mathrm{km}^{2}$, eastern area) interpolated using seafloor morphologies.

\section{$53^{\circ} \mathrm{E}$ Amagmatic Segment}

In $2010 \mathrm{R} / \mathrm{V}$ Dayang Yihao mapped $\sim 11,000 \mathrm{~km}^{2}$ between the Gallieni and Gauss FZ's (Fig. 3).

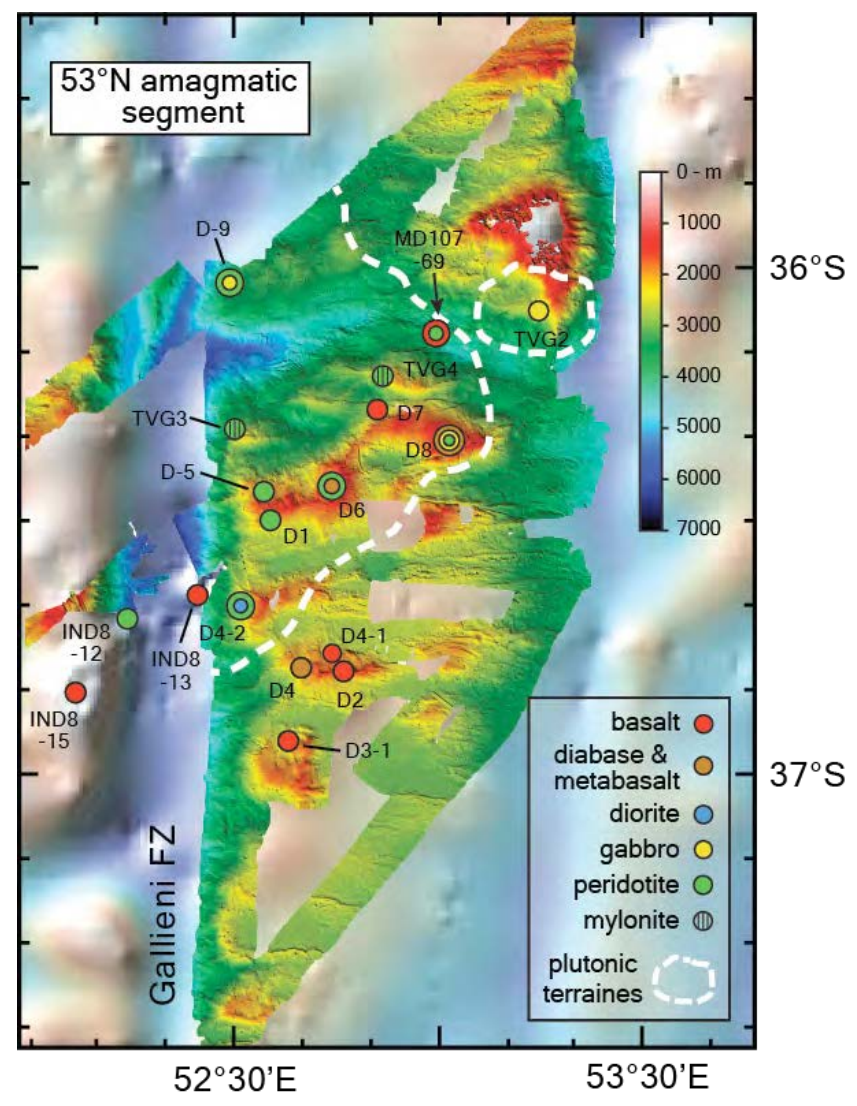

This comprised a ridge segment with a deep rift valley with 2.4-km relief at its mid-point, plunging from 3.9-km water depth to $>5-\mathrm{km}$ deep at the 107-km-offset Gallieni FZ. The rift valley lacks an axial high, and is bowed north at its center. Eleven dredges and three TV grabs collected $\sim 1938 \mathrm{~kg}$ of rock (Supplemental Table II). A Scripps cruise sampled peridotite (IND8-12) and basalt (IND8-15) from the western Gallieni Transform wall, and basalt low on the eastern wall (IND8-13), while the RV Marion Dufresne dredged 2 $\mathrm{kg}$ of dunite and $20 \mathrm{~kg}$ of basalt from the rift valley center.

Dayang Yihao recovered $422 \mathrm{~kg}$ of basaltic rock. Diabase occurred with peridotite in Dredge 6, and 8, with a small gabbro xenolith in one diabase. The remaining basalts were very fine to fine-grained, some with curved pillow rinds and one with glass. They are heavily weathered, but hydrothermally unaltered. Where associated with peridotite outcrops, they are likely hanging wall debris rafted on fault footwalls. A 250-kg gabbro block from the eastern inside-corner high and seafloor physiography indicates a possible $\sim 120-\mathrm{km}^{2}$ gabbroic core complex there, consistent with volcanic crust indicated by the E$\mathrm{W}$ lineated terrain in the eastern rift mountains.

Peridotite is extensively exposed in the eastern half of the segment and to the north and south in the rift-mountains flanking the Gallieni FZ. The western outside-corner high lacks well-developed ridge-parallel lineations, consisting of small domes where $204 \mathrm{~kg}$ of serpentinized peridotite and a small amount of gabbro were dredged. Seven stations in the southern rift mountains recovered $\sim 1062 \mathrm{~kg}$, mostly harzburgite. Three en-echelon 
domed ridges, progressively staggered to the north from the transform to the segment center, flank the western rift valley. They are $\sim 8-11 \mathrm{~km}$ wide and $\sim 20-28 \mathrm{~km}$ long, shoaling to 1000-2800 m depth, with the largest emerging from the center of the rift valley. TV grabs from the eastern and westernmost recovered serpentinized granular and mylonite peridotite. Immediately south of the easternmost, Dr 8 recovered diabase, gabbro and serpentinite from a large $28 \times 13 \mathrm{~km} \mathrm{N-S} \mathrm{corrugated} \mathrm{dome.} \mathrm{Further}$ southwest at $\sim 36^{\circ} 28$ 'S peridotite was dredged at three locations on another irregular $\sim 20$ $\mathrm{x} 35-\mathrm{km}$ domed region with evidence of N-S corrugations. Peridotite with a diorite fragment was found on the transform wall at the end of an E-W ridge at $36^{\circ} 40^{\prime}$ 'S (D4-2). Outside of these mantle exposures, only basalt was dredged to the southeast of D4-2, defining the limits of the mantle outcrops. The peridotite exposure flanking the Gallieni transform, then, is $\sim 110-\mathrm{km}$ in the spreading direction, and up to 60 -km wide, or $\sim 3200$ $\mathrm{km}^{2}$ - likely much bigger if the peridotite outcrops extend further north.

Compared to other large fracture zones, the uplift at the western inside-corner high is modest, composed of the three small axis-parallel domes, rather than one large dome, similar to those found on the opposing outside-corner high. These are distinct from more regularly lineated terrains characteristic of rifted volcanic crust in the eastern rift mountains. Such terrain is also inconsistent with the asymmetric detachment faulting seen at large oceanic core complexes. Rather it is generally associated with block faults exposing massive peridotite at amagmatic ridge segments ${ }^{16}$. The broader domes sampled by Dredges 1, 5, 6, and 8, however, feature corrugations and some mixed lithologies characteristic of oceanic core complexes. Bathymetry and dredging, then, indicate a progressive eastward transformation from magmatic to amagmatic spreading from $\sim 9.4$ Ma to present in the western portion of the $53^{\circ} \mathrm{E}$ segment (assuming symmetric spreading) with the formation of core complexes followed by more symmetric block faulting exposing an enormous region of partially serpentinized peridotite.

Spinel in 16 peridotites from 7 stations from the rift-mountains and eastern Gallieni FZ wall and 10 peridotites from 2 stations from the west wall have average $\mathrm{Cr} x$ 100/(Cr $+\mathrm{Al}$ ) 30 (Supplemental Table III) corresponding to $\sim 12.5 \%$ average melting ${ }^{32}$ of a hypothetical primitive upper mantle composition ${ }^{33}$. A basalt glass fragment from the $53^{\circ} \mathrm{E}$ segment has $\mathrm{Na}_{8.0}$ of 2.8; while those from the ridge to the east and west have average $\mathrm{Na}_{8.0}$ of 2.5, predicting $\sim 4-6 \mathrm{~km}$ of crust and a ridge depth of $\sim 2500 \mathrm{~m}^{20}-1000$ $\mathrm{m}$ shallower than what is actually observed.

\section{Crustal Architecture}

Abyssal peridotites have three principle emplacement modes: each with unique textures, distribution, and associations that allow their interpretation (see Methods Section). These include diapiric emplacement of highly sheared talc-serpentine schists and serpentinites along both low and high-angle faults cutting laterally or vertically through the crust into peridotite. Texturally, however, most abyssal peridotites are 
typical of those in large ophiolite peridotite massifs. Consistent with this, 65 of 119 SWIR peridotite dredges recovered no gabbro, and many of the rest only gabbro veins. A typical dredge covers 500 to $1000 \mathrm{~m}$, and multiple dredges often find little but peridotite in an area. A detachment fault exposing mantle peridotite from beneath 4-8 km of gabbro and basalt requires many kilometers of throw and heave, and gabbroic hanging wall debris should be scattered over the fault surface along with pillow lava and diabase. There would also be gabbro inliers in the footwall due to fault imbrication. Where ocean drilling or mapping has found massive gabbro, as at Atlantis Bank and Atlantis Massif, it is extensively exposed intruding peridotite on the transform wall (Fig. 2c, d). Similarly, at $23^{\circ} \mathrm{N}$ on the MAR gabbro complexes intruded into mantle peridotite were mapped by dredging ${ }^{34}$ and then confirmed and extended by seismic refraction ${ }^{35}$. A series of ODP holes in MAR tectonic windows at $14^{\circ}-16^{\circ} \mathrm{N}^{36}$ also confirm a plum pudding model of gabbro intrusions in serpentinized mantle ${ }^{37}$ constructed from bathymetry, dredging and diving. In these holes abundant gabbro veins and dikes were consistent precursors of larger gabbro bodies. The numerous gabbro veins and intrusions in peridotite on the Atlantis Massif transform wall (Fig. 2d) then telegraphed the 1400+ m gabbro body later drilled a few kilometers to the north. In all these cases, gabbro was far more abundant than generally along the SW Indian Ridge. Moreover gabbroic core complexes, such as Atlantis Bank ${ }^{38}$, Atlantis Massif ${ }^{18}$, Kane Megamullion ${ }^{19}$, and $23^{\circ} \mathrm{S}^{39}$ all show that where gabbroic crust is present, detachment faults root there, not in the mantle. Thus, based on textures and distribution the SWIR peridotite localities mainly represent massive partially serpentinized mantle exposed over large seafloor regions.

Thus sampling shows thin or missing crust over the Marion Rise. While peridotite is exposed on transform walls by detachment faulting rooted through the nearby dikegabbro transition, as at the Atlantis II FZ, in most areas the associated gabbro bodies had to be very small. Many peridotite exposures, as at $53^{\circ} \mathrm{E}$, are due to amagmatic spreading. Where gabbro is largely missing, the crust is likely limited to $<1-2-\mathrm{km}$ based on the known depths of the dike-gabbro - and hence the conductive-advective heat flow transition beneath ridges (e.g: ${ }^{40}$ ) (cooling is too rapid for gabbro to form in the advective cooling regime). In rare areas as at Atlantis Bank, where gabbro is abundant, the crust may be $4+\mathrm{km}^{18}$ thick, while in regions where largely mantle is exposed - near zero. With this degree of lateral heterogeneity a precise estimate of average crustal thickness is difficult. It is possible that in the eastern SWIR where 'smooth' seafloor indicative of block and detachment faulting predominates ${ }^{41}$, the average crust could be as little as 1$\mathrm{km}$, while over the Marion Swell where regions with more igneous crust may occur 2$\mathrm{km}$. But geologically, there is nothing like the crust available along the ridge sufficient to explain the Marion Rise by any model that precludes mantle compositional buoyancy as the major contributor. 


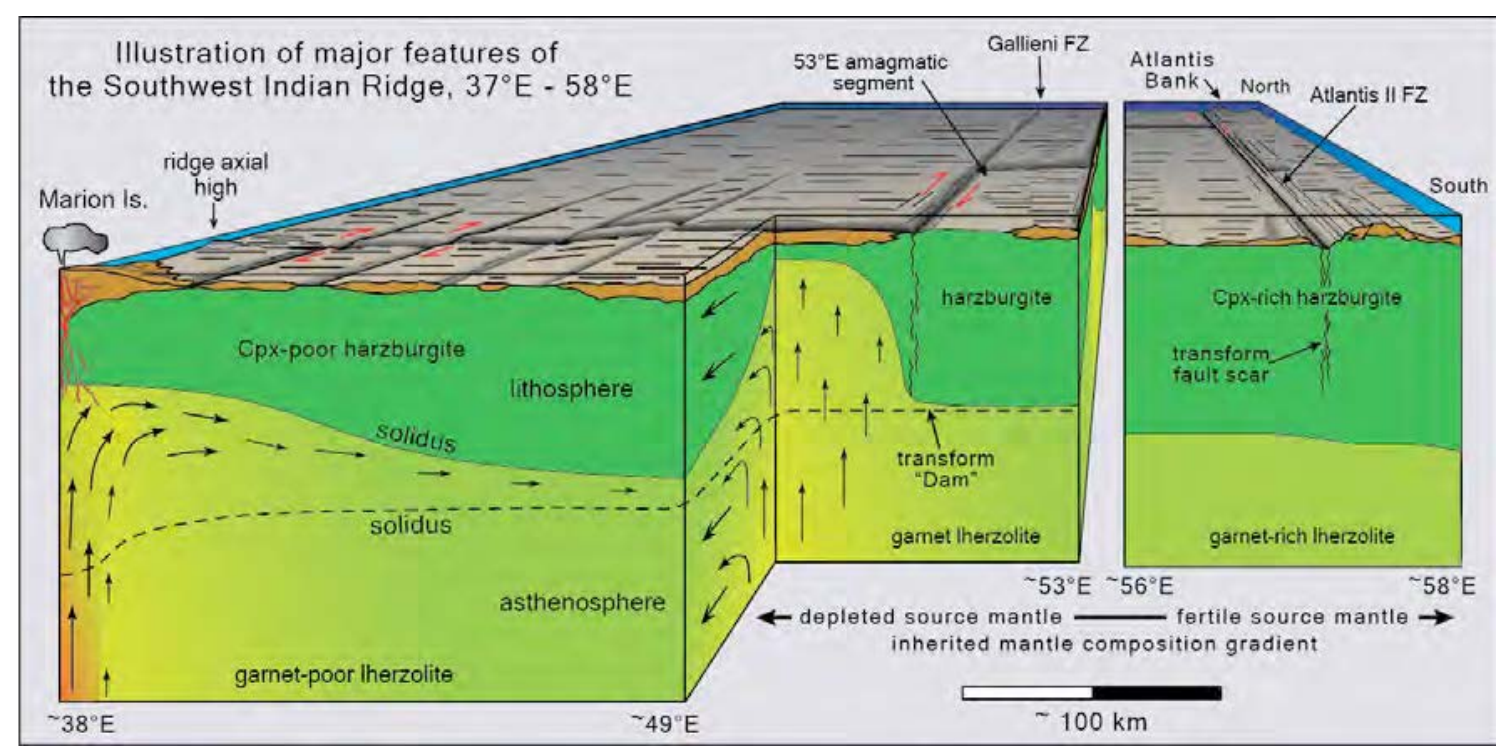

Figure 4 Cartoon looking north from the Antarctic Plate across the SWIR, showing the inferred crustal architecture along the Marion Rise. Note that transforms near Marion Island are not shown with the proper offsets to emphasize how a large-offset transform offsets the lithosphere and blocks sub-axial asthenospheric flow ${ }^{48}$. Left side of the cartoon illustrates the Atlantis Bank Oceanic Core Complex, which is shown on the front face of the diagram, though its actual position (indicated by arrow) is to the north, flanking the transform valley. Ridge section between $53^{\circ}$ and $56^{\circ} \mathrm{E}$ with several oblique amagmatic rifts ${ }^{49}$ is not shown.

\section{Discussion}

The numerous exposures of mantle peridotite and sparsity of gabbro over the Marion Rise overturns the iconic model that rises are all characterized by thick crust. This confirms the hypothesis that ocean rises can be supported by highly depleted buoyant mantle. Opposing models with uniform mantle composition and large variations in mantle potential temperature require correspondingly large variations in crustal thickness ${ }^{20}$. Differences between rifted and axial rises also cannot be attributed to spreading rate, as this is virtually uniform along the Marion Rise, and varies little up the Icelandic and Azores Rise, while the spreading rates of the rifted Marion and Azores Rises bracket that of the Icelandic (Table 1).

Without a large flux of hot primitive mantle or thick crust, a rifted rise can be supported by a thermal and/or compositional anomaly. For the latter case, Niu and O'Hara ${ }^{10}$ analyzing global ridge depth variability found no convincing evidence for ridge temperature gradients $>50^{\circ}-100^{\circ} \mathrm{K}^{10}$. They point out, however, that below $\sim 70 \mathrm{~km}$ in the garnet peridotite facies, the density difference between fertile garnet lherzolite and depleted harzburgite is very large ${ }^{10-12,42}$ - as much as $1.2 \%{ }^{10}$. Consistent with the large compositional variation of abyssal peridotites ${ }^{8}$, a $0.6 \%$ density contrast can easily account for the global ridge-depth variation, requiring compensation down to $458 \mathrm{~km}$.

Proportionately then, the local $2.1 \mathrm{~km}$ Marion Rise depth anomaly could be compensated in the upper 200-250 km entirely in the asthenosphere. Even assuming large temperature anomalies, however, it has been noted that the Hawaiian Swell, possibly the largest 
thermal plume on the planet, has a peak amplitude of only $\sim 1.4 \mathrm{~km}^{43}$ while Ito et al. ${ }^{44}$ modeling the Iceland Swell found little over $1 \mathrm{~km}$ supported by mantle temperature variations of $180^{\circ} \mathrm{C}$, with the rest being an isostatic response to crustal thickness. Thus, it is very unlikely that the geriatric Marion Plume could account for the 2.1-km depth anomaly along the Marion Rise.

Mantle composition gradients along rises can explain their gravity signal, which when modeled assuming uniform mantle composition, predicts 8 to $10 \mathrm{~km}$ of crust on the Marion and Azores Rises ${ }^{14,45}$. Varying serpentinization depth is not a likely alternative as serpentine is unlikely to be stable to 9 or $10 \mathrm{~km}$ depth beneath a ridge. Models for Moho as a serpentinization front attribute this to tectonic uplift into the rift mountains as the lithosphere cools into the serpentine stability field ${ }^{46}$. Where the Moho is likely a serpentinization front at the Gakkle Ridge, the seismic crust is only 1.9-3.3 km thick ${ }^{17}$. Such a front is controlled by the thermal structure at the ridge axis, and if anything its contribution should be negative to the depth anomaly if mantle temperature, and crustal thickness increase towards the high.

We show a large region of previously depleted mantle supports the Marion Rise rather than down-axis intrusion of hot primitive mantle (Fig. 7). Thin crust requires this as any thermal anomaly requires a more refractory mantle to offset the accompanying increase in melting. Absent an enormous thermal anomaly, mantle density variations seem the only possible explanation. The SWIR formed with the breakup of Gondwanaland $180 \mathrm{Ma}$, and the asthenosphere beneath the ridge was drawn up from beneath Southern Africa, Madagascar, and Antarctica. Thus, it likely represents the depleted source mantle for the Karoo, Madagascar, and Ferrar flood basalt events emplaced into the asthenosphere. In the event that this represents compositionally buoyant mantle plumes, the depletion may go back even further in Earth history.

The other major rifted rise, the Azores is similar to the Marion. It has only a 95-km long axial high at its crest, and a deep axial rift along the rest of its 2900-km length. Despite a focus on the neovolcanic zone, like the Marion, almost happenstance sampling has found peridotites exposed at numerous locations up its length (Supplemental Fig. 3). In conclusion, then, there are two classes of rise: axial and rifted - one robustly magmatic, the other anemic. While their associated hotspots and tracks indicate related origins, the dramatic differences between them require explanation. The proposition that, in large part, the former are supported by present-day melting anomalies, while the latter by mantle residues from the earlier history of their associated plumes seems entirely sensible.

\section{Methods Summary}

To interpret the crustal architecture along the SW Indian Ridge, we collected as much detailed information on their proportions, state of alteration, tectonic and igneous fabrics, and primary igneous petrology as we could. This data was then used to identify 
the likely manner in which they were exposed to the seafloor, whether emplaced as large massifs by detachment faulting, or serpentine diapirism up high-angle faults that cut either vertically or laterally into mantle rock. Particular care was taken to exclude talcserpentine and talc-tremolite schists, and highly sheared serpentinites when assessing the proportion of mantle rocks collected from the seafloor as reflecting major basement outcrops.

Critical to our methodology are mantle and lower crustal rocks exposed by detachment faults at oceanic spreading centers. These faults often operate for millions of years, exposing peridotite and gabbro on their footwalls, while the volcanic carapace spreads in the opposite direction. This produces oceanic core complexes that can expose many hundreds of $\mathrm{km}^{2}$ of plutonic rock on the seafloor, providing sections into the deep crust and upper mantle of regional significance. Their discovery and exploration over the last 20 years has revolutionized our understanding of crustal accretion at slow and ultraslow spreading ocean ridges. A further development, as discussed in the paper, is the discovery of large areas along the SW Indian Ridge where there is little igneous crust, and mantle rock spreads onto the seafloor in both directions by extensional block faulting at amagmatic accretionary ridge segments. Thus, interpretation of the data used in this paper is a product of many years of exploration of plutonic rocks outcropping on the seafloor, as well as ocean drilling deep sections into lower crust and mantle massifs, which has led to an understanding of the mechanisms by which they are emplaced and their tectonic significance.

Acknowledgements This work was supported by the Chinese National Key Basic Research Program (2012CB417300), China Ocean Mineral Resources Research and Development Association, and the US National Science Foundation (Grant OCE0526905). We would also like to thank the crew and scientists of RV Dayang Yihao Cruise 21. Margaret Sulanowska provided technical support, Zhiqian Chen and Yang Liu generously analyzed chrome spinels for us at the Guangzhou Institute of Geochemistry, CAS. A glass sample from $53^{\circ} \mathrm{E}$ was analyzed by Fuwu JI at the State Key Laboratory for Mineral Deposits Research, Nanjing University. Curatorial support and access to samples are gratefully acknowledged to the Core and Rock Storage Facility of the Woods Hole Oceanographic Institution. Daniel Sauter, Robert Fisher, and Enrico Bonatti provided additional unpublished sample descriptions and locations for the eastern and western Southwest Indian Ridge. Useful reviews were provided by Yaoling Niu, and an anonymous reviewer who encouraged us to provide more appropriate measurements of ridge depth and directed us to several important papers, greatly benefiting the manuscript and its conclusions. John VanDecar, our editor, whose efforts have led to a better manuscript.

Author Contributions: This article represents the first report of results from Cruise RV Dayang Yihao directed by the first author, who also had additional analytical work done 
at his institution. The second author collected the bulk of the sample data over a period of 35 years. Both authors participated in interpretation of the results, with the second primarily responsible for the written text.

\section{References}

1 Morgan, W. J. Deep mantle convection plumes and plate motions. American Association of Petroleum Geologists Bulletin 56, 203-213 (1972).

2 Kincaid, C., Schilling, J.-G. \& Gable, C. The dynamics of off-axis plume-ridge interaction in the uppermost mantle. Earth and Planetary Science Letters 137, 2943 (1996).

3 Weir, R. W. et al. Crustal structure of the northern Reykjanes Ridge and Reykjanes Peninsula, southwest Iceland. Journal of Geophysical Research 106, 6347-6368 (2001).

4 Ito, G. \& Behn, M. D. Magmatic and tectonic extension at mid-ocean ridges: 2. Origin of axial morphology. Geochemistry, Geophysics, Geosystems 9, 20, doi:10.1029/2008GC001970 (2008).

5 Wang, T., Lin, J., Tucholke, B. \& Chen, Y. J. Crustal thickness anomalies in the North Atlantic Ocean basin from gravity analysis. Geochemistry, Geophysics, Geosystems 12, 25 pp, doi:10.1029/2010GC003402 (2011).

6 Canales, J. P., Ito, G., Detrick, R. S. \& Sinton, J. Crustal thickness along the western Galapagos Spreading Center and the compensation of the Galapagos hotspot swell. Earth and Planetary Science Letters 203, doi:org/10.1016/S0012821X(02)00843-9 (2002).

7 Cannat, M., Rommevaux-Jestin, C., Sauter, D., Deplus, C. \& Mendel, V. Formation of the axial relief at the very slow spreading Southwest Indian Ridge ( $49^{\circ}$ to $69^{\circ} \mathrm{E}$ ). Journal of Geophysical Research 104, 22,825-822,843 (1999).

8 Dick, H. J. B., Fisher, R. L. \& Bryan, W. B. Mineralogic variability of the uppermost mantle along mid-ocean ridges. Earth and Planetary Science Letters 69, 88-106 (1984).

9 Georgen, J. E., Lin, J. \& Dick, H. J. B. Models of mantle upwelling beneath the Southwest Indian Ridge: the effects of ridge-transform geometry on magma supply at an ultra-slow spreading ridge. EOS, Transactions of the American Geophysical Union 79, 854 (1998).

10 Niu, Y. \& O'Hara, M. J. Global correlations of ocean ridge basalt chemistry with axial depth: a new perspective. Journal of Petrology 49, 633-664, doi:10.1093/petrology/egm051 (2008).

11 O'Hara, M. J. Is there an Icelandic mantle plume? Nature 253, 708-710 (1975).

12 Presnall, D. C. \& Helsley, C. E. Diapirism of depleted peridotite - a model for the origin of hot spots. Physics of the Earth and Planetary Interiors 29, 148-160 (1982).

13 Muller, M. R., Minshull, T. A. \& White, R. S. Segmentation and melt supply at the Southwest Indian Ridge. Geology 27, 867-870 (1999).

14 Zhang, T., Lin, J. \& Gao, J. Y. Interactions between hotspots and the Southwest Indian Ridge during the last $90 \mathrm{Ma}$ : Implications on the formation of oceanic plateaus and intra-plate seamounts. Science China Earth Science 54, 12 pp., doi:10.007/s11430-011-4219-9 (2011). 
15 Muller, M. R., Robinson, C. J., Minshull, T. A., White, R. S. \& Bickle, M. J. Thin crust beneath ocean drilling program borehole 735B at the Southwest Indian Ridge? Earth and Planetary Science Letters 148, 93-107 (1997).

16 Cannat, M. et al. Modes of seafloor generation at a melt-poor ultraslow-spreading ridge. Geology 34, 605-608 (2006).

17 Jokat, W. et al. Geophysical evidence for reduced melt production on the superslow Gakkel Ridge (Arctic Ocean). Nature 423, 962-965 (2003).

18 Dick, H. J. B. et al. A Long In-Situ Section of the Lower Ocean Crust: Results of ODP Leg 176 Drilling at the Southwest Indian Ridge. Earth and Planetary Sciences 179, 31-51 (2000).

19 Dick, H. J. B., Tivey, M. A. \& Tucholke, B. E. Plutonic foundation of a slowspreading ridge segment: Oceanic core complex at Kane Megamullion, $23^{\circ} 30^{\prime} \mathrm{N}$, 4520'W. Geochemistry, Geophysics, Geosystems 9, 44, doi:doi:10.1029/2007GC001645 (2008).

20 Klein, E. M. \& Langmuir, C. H. Global correlations of ocean ridge basalt chemistry with axial depth and crustal thickness. Journal of Geophysical Research 92, 8089-8115 (1987).

21 Patriat, P. \& Segoufin, J. Reconstruction of the Central Indian Ocean. Tectonophysics 155, 211-234 (1988).

22 Sclater, J. G., Grindlay, N. R., Madsen, J. A. \& Rommevaux-Jestin, C. Tectonic interpretation of the Andrew Bain transform fault: Southwest Indian Ocean. Geochemistry, Geophysics, Geosystems 6, 21 pp (2005).

23 Duncan, R. A. Hot spots in the southern oceans - an absolute frame of reference for the motion of the Gondwana continents. Tectonophysics 74, 29-42 (1981).

24 Georgen, J. E., Lin, J. \& Dick, H. J. B. Evidence from gravity anomalies for interactions of the Marion and Bouvet hotspots with the Southwest Indian Ridge: effect of transform offsets. Earth and Planetary Science Letters 187, 283-300 (2002).

25 Dick, H. J. B., Lin, J. \& Schouten, H. An ultraslow-spreading class of ocean ridge. Nature 426, 405-412 (2003).

26 Fisher, R. L., Dick, H. J. B., J., N. \& Meyer, P. S. Mafic/ultramafic suites of the slowly spreading Southwest Indian Ridge: PROTEA Exploration of the Antarctic Plate Boundary, $24^{\circ} \mathrm{E}-4^{\circ} \mathrm{E}$. Ophioliti 11, 147-178 (1986).

27 le Roex, A. P., Dick, H. J. B. \& Fisher, R. L. Petrology and geochemistry of MORB from $25^{\circ} \mathrm{E}$ to $46^{\circ} \mathrm{E}$ along the Southwest Indian Ridge: evidence for contrasting styles of mantle enrichment. Journal of Petrology 30, 947-986 (1989).

28 Dick, H. J. et al. How variable slow-spread ocean crust. EOS, Transactions of the American Geophysical Union 84 (2003).

29 Dick, H. J. B. in Magmatism in the Ocean Basins, Geological Society Special Publication No. 42 (eds A.D. Saunders \& M.J. Norry) 71-105 (1989).

30 Jaroslow, G. E., Hirth, G. \& Dick, H. J. B. Abyssal peridotite mylonites: implications for grain-size sensitive flow and strain localization in the oceanic lithosphere. Tectonophysics 256, 17-37 (1996).

31 Ildefonse, B. et al. Oceanic core complexes and crustal accretion atslowspreading ridges. Geology 35, 623-626 (2007). 
32 Hellebrand, E., Snow, J. E., Dick, H. J. B. \& Hofmann, H. Coupled major and trace-element indicators in mid-ocean ridge peridotites. Nature 410, 677-681 (2001).

33 Sun, S.-s. Chemical composition and origin of the earth's primitive mantle. Geochimica et Cosmochimica Acta 46, 179-192 (1982).

34 Dick, H. J., Tivey, M. A., Tucholke, B. E. \& Cheadle, M. J. The plutonic foundation of a MAR ridge spreading segment: The Kane Oceanic Core Complex. Eos Trans. AGU 86, Abstract T33G-02 (2005).

35 Xu, M., Canales, J. P., Tucholke, B. E. \& DuBois, D. L. Heterogeneous seismic velocity structure of the upper lithosphere at Kane oceanic core complex, MidAtlantic Ridge. Geochemistry, Geophysics, Geosystems 10, 34 pp, doi:10.1029/2009GC002586 (2009).

36 Kelemen, P. B. et al. Proceedings of the Ocean Drilling Program, Part A: Initial Reports, vol.209. Vol. 209 (Ocean Drilling Program, Texas A\&M University, 2004).

37 Cannat, M. et al. Ultramafic and gabbroic exposures at the Mid-Atlantic Ridge: geologic mapping in the $15^{\circ} \mathrm{N}$ region. Tectonophysics 279 (1997).

38 Blackman, D. K. et al. Proceedings of the Integrated Ocean Drilling Program. Vol. 304/305 (Integrated Ocean Drilling Program Management International, 2006).

39 Moroshita, T. et al. Igneous, alteration and exhumation processes recorded in abyssal peridotites and related fault rocks from an oceanic core complex along the Central Indian Ridge. Journal of Petrology 50, 1299-1325 (2009).

40 Teagle, D. A. et al. Drilling a complete in situ section of upper oceanic crust formed at a superfast spreading rate: Hole 1256D. Eos Trans. AGU 87 (52), Abstract B31B-1090 (2006).

41 Cannat, M., Sauter, D., Escartin, J., Lavier, L. \& Picazo, S. Oceanic corrugated surfaces and the strength of the axial lithosphere at slow spreading ridges. Earth and Planetary Science Letters 288, 174-183 (2009).

42 Jordan, T. H. in The Mantle Sample: Inclusions in Kimberlites and Other Volcanics, Proceedings of the Second International Kimberlite Conference Vol. 2 (eds F.R. Boyd \& H.O.A. Meyer) 1-14 (American Geophysical Union, 1979).

43 Cadio, C., Ballmer, M. D., Panet, I., Diament, M. \& Ribe, N. New constraintsontheoriginoftheHawaiianswellfromwaveletanalysis of thegeoidtotopographyratio. Earth and Planetary Science Letters 359-360, 40-54, doi:doi.org/10.1016/j.epsl.2012.10.006 (2012).

44 Ito, G., Shen, Y., Hirth, G. \& Wolfe, C. J. Mantle flow, melting, and dehydration of the Iceland mantle plume. Earth and Planetary Science Letters 165, 81-96 (1999).

45 Detrick, R. S., Needham, H. D. \& Renard, V. Gravity anomalies and crustal thickness variations along the Mid-Atlantic Ridge between $33^{\circ} \mathrm{N}$ and $40^{\circ} \mathrm{N}$. Journal of Geophysical Research 100, 3767-3787 (1995).

46 Canales, J. P., Detrick, R. S., Lin, J., Collins, J. A. \& Toomey, D. R. Crustal and upper mantle seismic structure beneath the rift mountains and across a nontransform offset at the Mid-Atlantic Ridge. Journal of Geophysical Research 105, 2699-2720 (2000). 
47 Karson, J. A. et al. Detachment shear zone of the Atlantis Massif core complex, Mid-Atlantic Ridge, 30N. Geochemistry, Geophysics, Geosystems (G3) 7, 29 p., doi:10.1029/2005GC001109 (2006).

48 Georgen, J. E. \& Lin, J. Plume-transform interactions at ultra-slow spreading rates: Implications for the Southwest Indian Ridge. Geochemistry, Geophysics, Geosystems (G3) 4 (9) 9106, doi:10.1029/2003GC000542 (2003).

49 Dick, H. J., Lin, J., Michael, P. J., Schouten, H. \& Snow, J. E. Ultra-slowspreading - A New Class of Ocean Ridge. EOS, Transactions of the American Geophysical Union 83 (2002).

50 Dick, H. J. B., Arai, S., Hirth, G., John, B. J. \& KROO-06 Scientific Party. A subhorizontal cross-section through the crust mantle boundary at the SW Indian Ridge. Geophysical Research Abstracts 3, 794 (2001). 


\begin{tabular}{|c|c|c|c|c|c|c|c|c|c|c|}
\hline Rise & $\begin{array}{c}\text { Dominant } \\
\text { Morph- } \\
\text { ology }\end{array}$ & $\begin{array}{l}\text { Spreading } \\
\text { Rate } \\
\text { (mm/yr) }\end{array}$ & $\begin{array}{c}\text { Hotspot } \\
\text { Magma } \\
\text { Flux } \\
\left(\mathrm{m}^{3} / \mathrm{s}\right)^{\mathrm{a}}\end{array}$ & $\begin{array}{c}\text { Crustal } \\
\text { Vol. }{ }^{\mathrm{b}} \\
\left(10^{7} \mathrm{~km}^{3}\right)\end{array}$ & $\begin{array}{c}\text { Max } \\
\text { \&Min. } \\
\text { Elevation } \\
(\mathrm{m})^{c}\end{array}$ & $\begin{array}{l}\text { Max \&Min. } \\
\text { Elevation, } \\
200 \mathrm{~km} \text { ave. } \\
(\mathrm{m})^{\mathrm{d}}\end{array}$ & \begin{tabular}{|c|} 
Depth \\
Anoma \\
ly \\
$(\mathrm{m})^{\mathrm{e}}$
\end{tabular} & $\begin{array}{l}\text { Rise } \\
\text { Length } \\
(\mathrm{km})^{\mathrm{c}}\end{array}$ & $\begin{array}{l}\text { Cross- } \\
\text { section } \\
\text { Area } \mathrm{km}^{2}\end{array}$ & $\begin{array}{c}\text { Geographic } \\
\text { Location }\end{array}$ \\
\hline Iceland & Axial high & 19.5 & 7.0 & 4.53 & $\begin{array}{c}750 \\
-3115 \mathrm{~m}\end{array}$ & $\begin{array}{c}642 \\
-2425\end{array}$ & 3067 & 2390 & $3,665,156$ & $\begin{array}{c}\text { Jan Mayen to } \\
\text { Gibbs FZ @ 53오 }\end{array}$ \\
\hline Galapagos & Axial high & 63.0 & 5.5 & & $\begin{array}{l}-1361 \\
-3732\end{array}$ & $\begin{array}{l}-1762 \\
-3170\end{array}$ & 1408 & 1380 & 970,988 & $\begin{array}{c}\text { ocos Nazca Ridge } \\
\text { @ 2 }{ }^{\circ} \mathrm{N}\end{array}$ \\
\hline Azores & Axial rift & 20.5 & & 1.15 & $\begin{array}{l}-345 \\
-4127\end{array}$ & $\begin{array}{l}-1659 \\
-3441\end{array}$ & 1782 & 2877 & $2,563,557$ & $\begin{array}{c}\text { MAR } 47.5^{\circ} \text { to } \\
25.8^{\circ} \mathrm{N}\end{array}$ \\
\hline Marion & Axial rift & 14.6 & 0.4 & 0.95 & $\begin{array}{l}-858 \\
-5150\end{array}$ & $\begin{array}{l}-2547 \\
-4681\end{array}$ & 2134 & 3408 & $3,636,236$ & \begin{tabular}{|c|} 
SWIR \\
$32.32^{\circ}$ to $63.34^{\circ} \mathrm{E}$
\end{tabular} \\
\hline
\end{tabular}

Notes: a) Marion - Zhang et al. ${ }^{14}$; b) Iceland\& Azores - Wang et al. ${ }^{5}$; Galapagos - Canales et al. ${ }^{6}$; Marion - Zhang et al. ${ }^{14}$. c) Maximum and minimum elevations are measured from shallowest point on axis, or midpoint of Iceland plateau to the rift valley axis point where average depth stabilizes or blocking transform. d) The 200-km average represents average elevation about the highest or lowest point. e) Iceland average plateau height; crest of Azores Rise, SWIR @ 36¹5Ed) MAR @ Charlie Gibbs FZ; axial

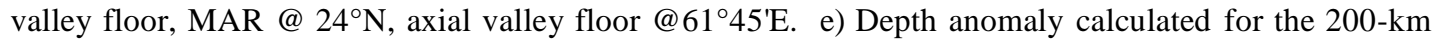
averages to eliminate local topographic effects. Note that measured by the total rise length and rise height, the Iceland and Marion Rises are equally large within error ( 1/2 x Height $\mathrm{x}$ Length). 


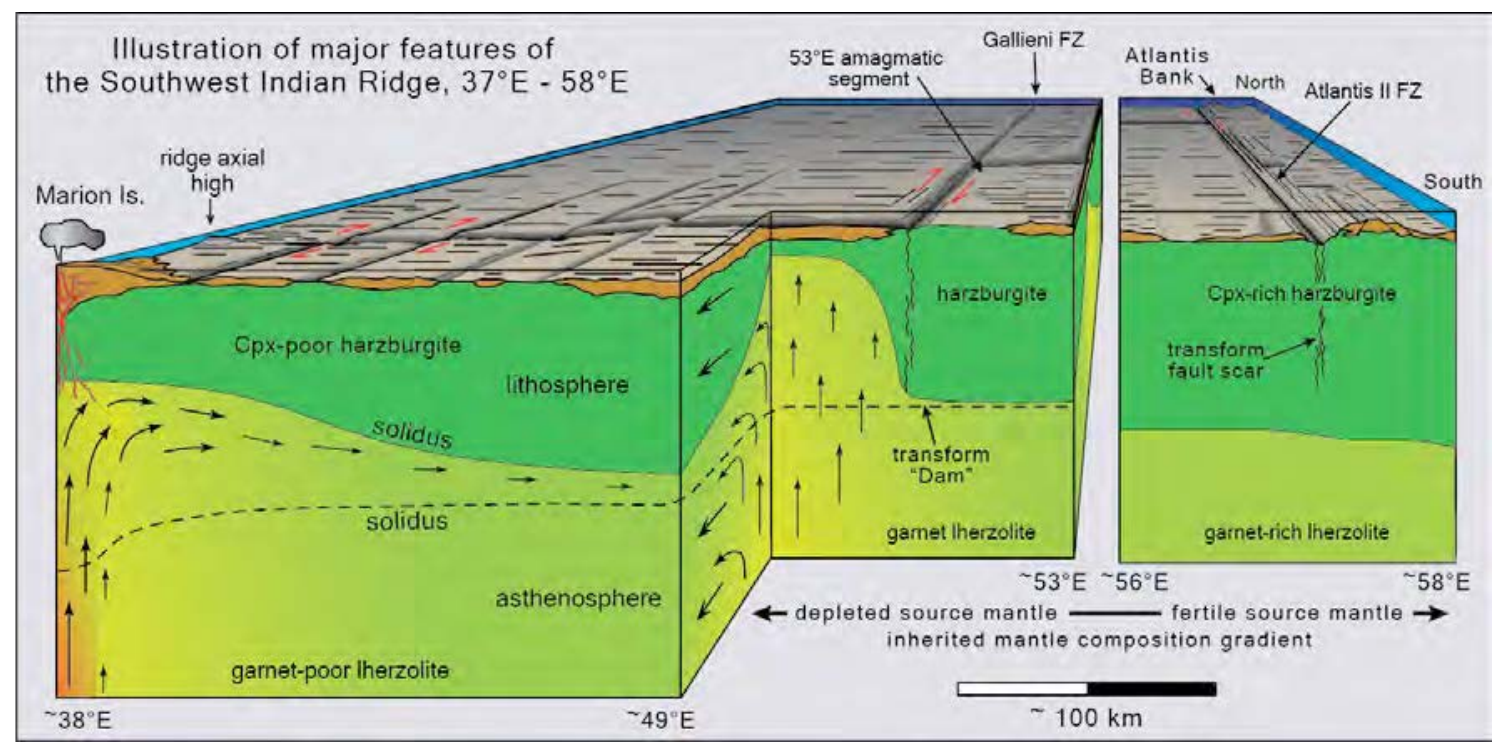

Figure 4 Cartoon looking north from the Antarctic Plate across the SWIR, showing the inferred crustal architecture along the Marion Rise. Note that transforms near Marion Island are not shown with the proper offsets to emphasize how a large-offset transform offsets the lithosphere and blocks sub-axial asthenospheric flow ${ }^{48}$. Left side of the cartoon illustrates the Atlantis Bank Oceanic Core Complex, which is shown on the front face of the diagram, though its actual position (indicated by arrow) is to the north, flanking the transform valley. Ridge section between $53^{\circ}$ and $56^{\circ} \mathrm{E}$ with several oblique amagmatic rifts ${ }^{49}$ is not shown.

\section{Methods}

The interpretation of crustal and upper mantle structure and architecture using seafloor samples is based on understanding of the physical features of the samples: their igneous, metamorphic, and structural characteristics, the tectonic setting in which they were collected, and the local seafloor physiography. Major features, such as detachment faults, high-angle normal faults, and transform walls provide exposures of the lower crust and mantle that can easily be misinterpreted. Here we summarize many of the key characteristics that guided our interpretation of the samples collected along the SW Indian Ridge, not discussed in the main text of the paper.

Although a relatively small proportion of mantle derived rocks sampled along the SW Indian Ridge, talc-tremolite and talc-serpentine schists can result in misinterpretation of basement lithology. While such schists represent a small percentage of SW Indian Ridge peridotites, certainly $<10 \%$ (Supplemental Fig. 1), accounting for these is important to our methodology for interpreting crustal architecture. Prior to IODP drilling at Atlantis Massif, such rocks gave the perception that basement there was massive peridotite. However, 1400-m of largely gabbro was drilled instead. Evidently the schists and included mylonite fragments found on the massif ${ }^{47}$ were intruded along the detachment fault from where it cut peridotite emplaced in the transform domain to where it rooted in gabbro. These schists also occur in-situ at Atlantis Bank ${ }^{50}$ lying on 850-m of 
massive gabbro outcrop, and at Kane Megamullion on the MAR as fault gouge on statically altered massive peridotite and dynamically deformed gabbro ${ }^{19}$. They represent meters thick skins, originally intruded along, and then exposed on, the footwalls of detachment faults, and are excluded in our interpretation of crustal architecture along the SWIR.

Another important consideration is serpentine diapirism up high-angle normal faults that cut into mantle rock at depth. This is seen in the western US Klamath Mountains, where peridotite hydrated to serpentinite studied by the co-author is emplaced diapirically along high-angle faults cutting vertically or laterally into peridotite. This produces serpentinite belts up to 100-m's wide extending up to many tens of kilometers between unrelated metavolcanics and greywackes. They are highly deformed and sheared, often with facoidal peridotite blocks preserving primary granular textures. Missing are talc-serpentine schists, entrained mylonites, and any evidence of hightemperature faulting. This mode, representing late faulting and hydration of peridotite above the brittle-ductile transition, can account for the serpentinites in-faulted into lavas and gabbros in several shallow DSDP ${ }^{51}$ and ODP ${ }^{52}$ MAR holes on the Azores Rise. Consequently, while the occurrence of highly sheared serpentinites support the idea that the crust may be thin, they do not provide direct evidence that the latter is missing.

Critical to our methodology is mantle and lower crust interpreted as emplaced to the seafloor by detachment faults where these rocks spread in one direction as the volcanic carapace spreads in the other ${ }^{53}$. These faults commonly operate for millions of years ${ }^{54,55}$, requiring enormous heave and throw, producing distinctive bathymetric terrain $16,25,56$. Almost half the MAR seafloor from $12.5^{\circ}$ to $35^{\circ} \mathrm{N}$ formed by such asymmetric spreading ${ }^{57}$. At ultraslow ridges, peridotite is also emplaced over large areas by more symmetric block faulting at amagmatic ridge segments where the lithosphere is too strong to sustain low-angle faults ${ }^{16,25,58,59}$. The associated high-temperature mylonites show both these fault classes rooted at high temperatures in the brittle-ductile transition in the mantle. Dredging, diving and drilling have documented many such large mantle massifs as at the MAR from $14^{\circ}$ to $16^{\circ} \mathrm{N}^{36,37,60,61}$, Kane Megamullion ${ }^{19}$, and on the SW Indian Ridge ${ }^{25,62}$, as we also report here for the SW Indian Ridge at $53^{\circ} \mathrm{E}$.

Thus, interpretation of the rock data used in this paper to decipher crustal architecture along the SW Indian Ridge is a result of many years of exploration of plutonic rocks outcropping on the seafloor by dredging, submersible and ROV, as well as ocean drilling deep sections into lower crust and mantle massifs, which has led to an understanding of the mechanisms by which they are emplaced. 


\section{Thin Crust as Evidence for an Inherited Mantle Depletion Supporting the Marion Rise: Supplementary Information}

\section{Supplemental Figure 1 Representative peridotite lithologies. a, 1: Atlantis Bank, SWIR, transform wall statically serpentinized harzburgite with $\sim 90 \%$ serpentine stained black by dispersed magnetite replacing} olivine, and partially serpentinized enstatite with pseudomorphed porphyroclastic texture. 2: Atlantis Bank transform wall protogranular lherzolite with 10\% mesh-textured serpentine replacing olivine with $\sim 20 \%$ fresh enstatite and $\sim 5 \%$ diopside. Remaining olivine oxidized to light brown clay. b, 1-3: Talcserpentine schists from a 1-m talc-serpentine schist layer on the detachment fault footwall at Atlantis bank overlying 850-m of deformed oxide gabbro exposed in a land-slip headwall. c, Atlantis Massif, MAR, talc-tremolite schists from detachment fault footwall shear zone 48. 1-2: Bottom left: Talc-tremolite schist with facoidal fragments of peridotite mylonite and porphyroclastic peridotite ${ }^{48}$. 3: Talc-tremolite bands with enclaves of weathered partially serpentinized peridotite. Scale bars $=2 \mathrm{~cm}$.
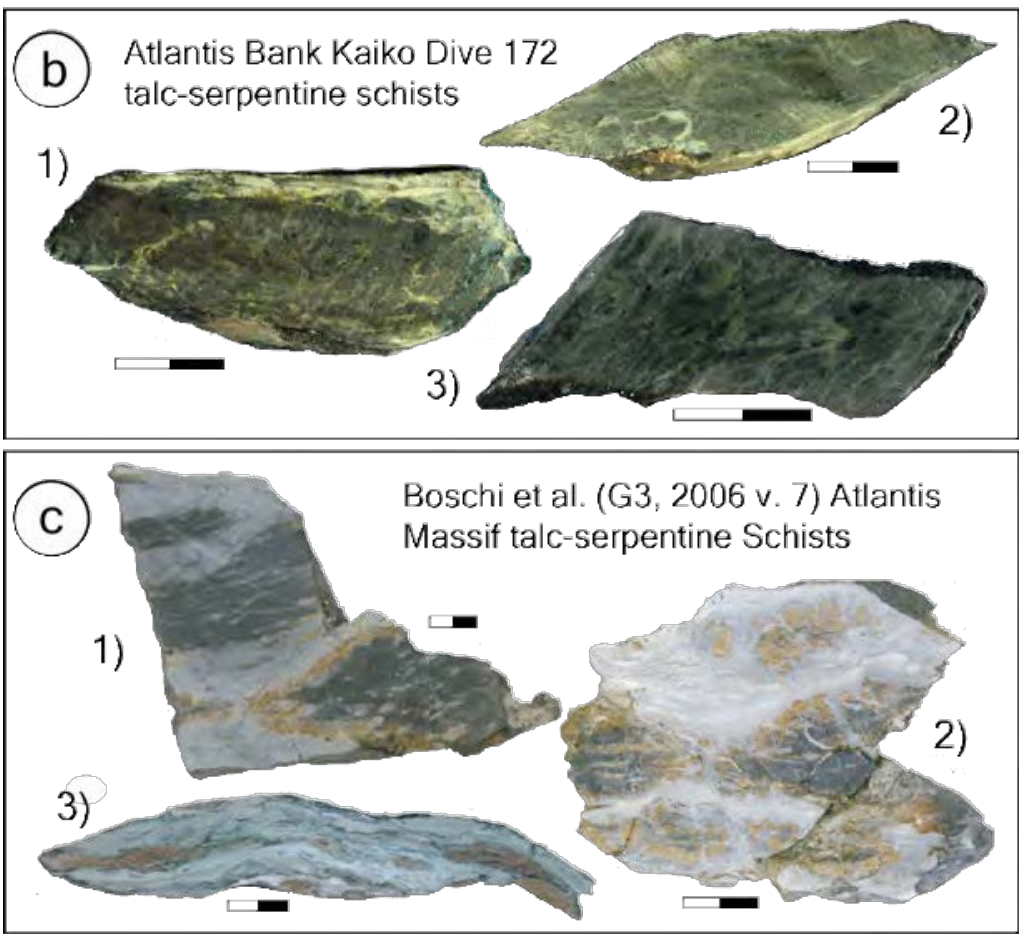

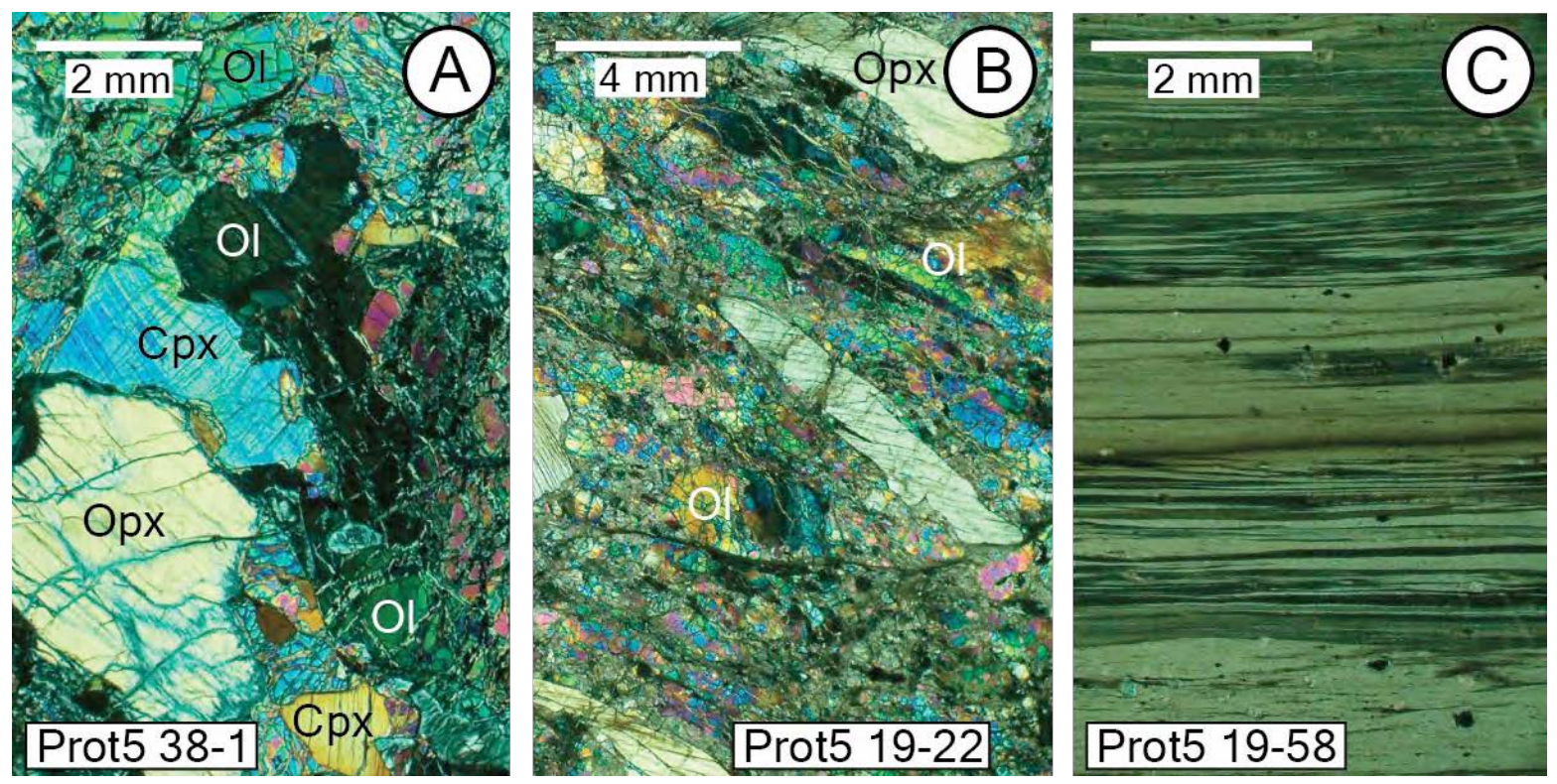

Supplemental Figure 2 Microphotographs of SWIR peridotites in cross-polarized light: Opx - enstatite, Cpx - diopside, Ol - olivine. Unlabeled material is relict olivine with fine mesh networks of grey serpentine veins. a, Protogranular Lherzolite Protea 538-1 Indomed Transform. b, Porphyroclastic Harzburgite Prot 5-19-22, Prince Edward Transform. c, Peridotite Mylonite Prot 5-19-58, Prince Edward Transform. 


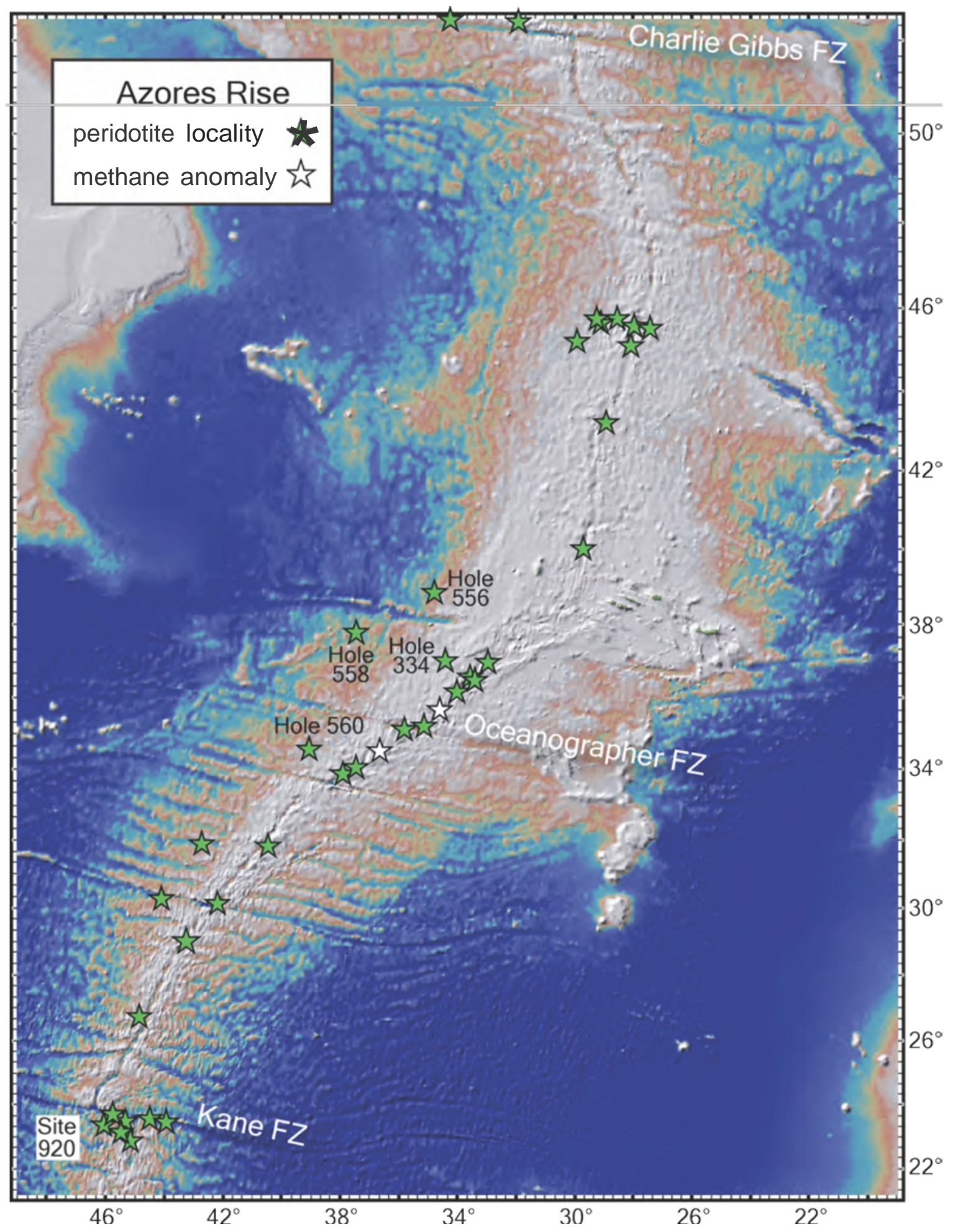

Supplemental Figure 3 Relief map of the Azores Rise made using GeoMapAp (www.geomapapp.org), showing the location of satellite navigated dredges and dives recovering peridotites. Also shown are the locations of methane anomalies indicative of mantle outcrops in areas where no seafloor sampling has occurred. 


\begin{tabular}{|c|c|c|c|c|c|c|}
\hline \multicolumn{7}{|c|}{$\begin{array}{l}\text { Supplemental Table II. Station Locations and Contents, } \\
\text { R/V Dayang Yihao Cruise DY21, Leg } 5\end{array}$} \\
\hline \multirow{2}{*}{ Station } & \multirow{2}{*}{ Sampler } & \multicolumn{2}{|c|}{ Sample location } & \multirow{2}{*}{$\begin{array}{l}\text { Water } \\
\text { Depth (m) }\end{array}$} & \multirow{2}{*}{$\begin{array}{l}\text { Total Wt. } \\
\quad(\mathrm{kg})\end{array}$} & \multirow{2}{*}{ Petrography } \\
\hline & & Longitude & Latitude & & & \\
\hline 21V-D1 & Dredge & 52.58821 & 36.50597 & 2045 & 450 & Serpentinized peridotite, Breccia \\
\hline 21V-S6-D2 & Dredge & 52.76721 & 36.80343 & 1789 & 83 & Pillow Basalt w/glass \\
\hline 21V-S7-D3-1 & Dredge & 52.64895 & 37.03333 & 1780 & 275 & Pillow Basalt \\
\hline 21V-S8-D4 & Dredge & 52.66344 & 36.79642 & 1866 & 2 & Diabase \\
\hline 21V-S8-D4-1 & Dredge & 52.7415 & 36.76317 & 1867 & 11 & Basalt \\
\hline 21V-S8-D4-2 & Dredge & 52.51546 & 36.67474 & 2388 & 150 & Serpentinized Peridotite, Diorite \\
\hline 21V-S9-D5 & Dredge & 52.572 & 36.44977 & 2040 & 100 & Serpentinized Peridotite \\
\hline 21V-S10-D6 & Dredge & 52.73844 & 36.4386 & 1524 & 250 & $\begin{array}{c}\text { Serpentinized Peridotite, } \\
\text { Metabasalt }\end{array}$ \\
\hline 21V-S11-D7 & Dredge & 52.84988 & 36.28759 & 2285 & 34 & Pillow Basalt \\
\hline 21V-S12-D8 & Dredge & 53.0254 & 36.34823 & 1187 & 17 & $\begin{array}{l}\text { Diabase, Troctolite, Gabbro, } \\
\text { Peridotite, Pumice }\end{array}$ \\
\hline 21V-S14-TVG2 & TV-Grab & 53.24396 & 36.0921 & 2237 & 250 & Gabbro \\
\hline 21V-S15-TVG3 & TV-Grab & 52.50108 & 36.3258 & 2806 & 50 & $\begin{array}{c}\text { Serpentinized Granular and } \\
\text { Protomylonite Peridotite }\end{array}$ \\
\hline 21V-S16-TVG4 & TV-Grab & 52.8631 & 36.2212 & 2089 & 62 & $\begin{array}{c}\text { Serpentinized Mylonite } \\
\text { Peridotite }\end{array}$ \\
\hline 21V-S17-D9 & Dredge & 52.48846 & 36.03636 & 3515 & 204 & $\begin{array}{c}\text { Serpentinized Peridotite, Dunite, } \\
\text { Gabbro }\end{array}$ \\
\hline
\end{tabular}




\begin{tabular}{|c|c|c|c|c|c|c|c|c|c|c|c|c|}
\hline Label & Pt's & $\mathrm{SiO}_{2}$ & $\mathrm{TiO}_{2}$ & $\mathrm{Al}_{2} \mathrm{O}_{3}$ & $\mathrm{Cr}_{2} \mathrm{O}_{3}$ & $\mathrm{Fe}_{2} \mathrm{O}_{3}$ & $\mathrm{FeO}$ & $\mathrm{MnO}$ & $\mathrm{MgO}$ & $\mathrm{CaO}$ & $\mathrm{NiO}$ & Total \\
\hline 21V-D1-4 & 7 & 0.02 & 0.05 & 43.5 & 25.2 & 1.32 & 12.4 & 0.21 & 17.1 & 0.00 & 0.27 & 100.1 \\
\hline 21V-D1-14 & 7 & 0.03 & 0.06 & 43.8 & 25.2 & 1.14 & 12.3 & 0.19 & 17.2 & 0.00 & 0.27 & 100.2 \\
\hline 21V-D1-15 & 10 & 0.03 & 0.06 & 43.2 & 26.1 & 0.90 & 13.0 & 0.19 & 16.8 & 0.00 & 0.25 & 100.5 \\
\hline 21V-S8-D4-2-3 & 11 & 0.02 & 0.07 & 44.9 & 23.2 & 1.96 & 11.9 & 0.15 & 17.5 & 0.00 & 0.31 & 100.0 \\
\hline 21V-S9-D5-3 Gr 1 & 7 & 0.02 & 0.09 & 47.2 & 21.7 & 1.41 & 10.0 & 0.14 & 19.0 & 0.00 & 0.36 & 99.9 \\
\hline 21V-S9-D5-3 Gr 2 & 5 & 0.02 & 0.08 & 47.6 & 20.9 & 1.63 & 11.6 & 0.18 & 18.1 & 0.00 & 0.30 & 100.3 \\
\hline 21V-S9-D5-4 & 11 & 0.02 & 0.08 & 47.5 & 21.3 & 1.08 & 11.9 & 0.11 & 17.9 & 0.00 & 0.30 & 100.3 \\
\hline 21V-S9-D5-6 & 7 & 0.02 & 0.07 & 47.7 & 20.9 & 1.41 & 11.4 & 0.10 & 18.2 & 0.00 & 0.33 & 100.2 \\
\hline 21V-S10-D6-5 & 6 & 0.07 & 0.07 & 38.0 & 30.5 & 1.14 & 15.0 & 0.23 & 14.9 & 0.00 & 0.16 & 100.2 \\
\hline 21V-S17-D9-10 & 7 & 0.10 & 0.06 & 42.5 & 25.8 & 1.27 & 12.9 & 0.14 & 16.7 & 0.08 & 0.22 & 99.8 \\
\hline 21V- S17-D9-18 & 10 & 0.06 & 0.13 & 41.2 & 26.1 & 1.47 & 16.4 & 0.16 & 14.4 & 0.00 & 0.22 & 100.1 \\
\hline 21V- S17-D9-6 & 5 & 0.08 & 0.02 & 36.2 & 33.8 & 0.70 & 13.3 & 0.20 & 15.8 & 0.14 & 0.16 & 100.3 \\
\hline 21V- S17-D9-9 & 6 & 0.06 & 0.07 & 46.6 & 21.5 & 1.16 & 13.6 & 0.14 & 16.6 & 0.00 & 0.32 & 100.1 \\
\hline 21V-TVG3 & 6 & 0.04 & 0.08 & 49.4 & 16.9 & 2.04 & 13.1 & 0.12 & 17.1 & 0.00 & 0.31 & 99.1 \\
\hline 21V-TVG3-5 & 7 & 0.01 & 0.08 & 49.5 & 17.4 & 1.75 & 14.0 & 0.19 & 16.6 & 0.00 & 0.32 & 99.9 \\
\hline 21V-TVG4 & 7 & 0.01 & 0.07 & 35.9 & 33.9 & 0.80 & 14.0 & 0.16 & 15.4 & 0.00 & 0.17 & 100.5 \\
\hline 21V-TVG4-2 & 8 & 0.04 & 0.05 & 37.6 & 31.1 & 1.85 & 13.1 & 0.20 & 16.1 & 0.00 & 0.19 & 100.4 \\
\hline
\end{tabular}

Ferric and ferrous iron computed from mineral stoichiometry. Gr stands for grain \# where more than one was analyzed. Additional spinel analyses for earlier dredges used in the text are from Dick (pers. Comm.). 